\title{
A Special Case of International Migration: Ethnic Hungarians Migrating From Transylvania to Hungary
}

\author{
IRÉN GÖDRI, Research Fellow \\ Demographic Research Institute, \\ Hungarian Central Statistical Office, Budapest, Hungary
}

\begin{abstract}
The study examines a special case of international migration, when the ethnicity, mother tongue, historical and cultural traditions of the immigrants are identical with those of the receiving population. This is also a fundamental feature of immigration to Hungary in the last decade and a half and could be observed primarily in the migratory wave from neighboring countries (most of all from Transylvania in Romania). After presenting the historical background we will review the development of the present-day migratory processes as well as their social and economical conditions, relying on statistics based on various sources. The socio-demographic composition of the immigrants and their selection from the population of origin indicate that migration is more frequent among younger, better-educated people living in an ethnically heterogeneous urban environment. At the same time, the rising proportion of older people and pensioners among the immigrants suggests the commencement of the so-called "secondary migration." This is confirmed by a questionnaire-based survey conducted among immigrants, which showed that family reunification is a migratory motivation for a significant group of people, primarily for the older generation. Among younger people economic considerations are decisive in the migrants' decision-making. Our analysis underscores the roles of ethnicity and network of connections in the processes under examination.
\end{abstract}

Keywords: international migration, Hungary, ethnic minority, Transylvania, ethnicity, network

\section{Introduction}

Due primarily to the social and political transformations in Eastern and Central Europe, we have been witnessing significant changes after the end of the 1980s in migratory patterns in Hungary. After decades of isolation, Hungary has again joined the international currents of migration and the related changes pose challenges both to researchers of the topic and political decision-makers. 
After the large wave of migration in 1988-1989 from neighboring Romania, significant masses of people crossed into Hungary with a view to permanent settlement and as a consequence of the Balkan Wars, the number of refugees was also rather high, especially in the early 1990s (for more details, cf. Tóth 1996a). Hungary had become a receiving country and considering that some of the migrants arriving in Hungary in the early years have since gone on to other countries since, it has also become a transit country.

The population decline that started in Hungary about two decades ago is not counterposed by the immigrant population, but the people who elect to stay in Hungary permanently will in the long run play a significant part in shaping the country's population figures, gender and age composition and possibly other demographic processes as well (Hablicsek and Tóth 1996).

In the course of the past decade and a half, the fundamental feature of migration to Hungary was revealed: namely, that Hungary is a destination country primarily for Hungarians living outside its borders. The majority of people moving to Hungary with a view to settling or staying for a long time migrate from neighboring countries and are of Hungarian ethnicity. The migration of Hungarian ethnic minorities to their "mother country" constitutes a peculiar case of international migration and investigating and understanding it demand some knowledge of the historical background. Since the majority of immigrants coming to Hungary are of the same language and culture as the receiving population, the move does not bring them minority status in the new country but an exit from their minority status in the homeland.

In the 1990s, some two thirds of all immigrants came to Hungary from neighboring countries and $46 \%$ of them from a single country: Romania. This is why we will analyze migration from Romania to Hungary in the subsequent pages and illustrate all those features that had a role in setting off and maintaining this migration. We will also analyze changes in the immigrants' composition, the features of their selection from the population of origin and the temporal changes in their migratory motivations.

\section{Historical background}

Of Hungary's neighboring countries, Romania has the highest number of ethnic Hungarians (the latest census at 2002 put their number at 1.43 million) and $98.5 \%$ of them live in one historical province, Transylvania. When the 1920 Paris peace treaties gave Transylvania, then part of the Austro-Hungarian Monarchy, to Romania, 1.66 million Hungarians became Romanian citizens without ever leaving their homeland. (Another 1.5 million Hungarians lived in other territories given to other neighboring countries, for more details, c.f. Tóth 1996b.) 
For those Hungarians living in the annexed territories, the fact that their homeland was separated from the mother country and attached to a foreign country also meant that they moved from being the dominant ethnicity to a minority status. The Romanian military occupation of Transylvania set off a wave of migration to Hungary at the end of 1918 and this continued after the peace treaties. Besides the psychological burden of minority status, the Romanian state also exerted pressure on ethnic Hungarians which contributed to migration to Hungary. Instances of such pressure were the oath of loyalty and the compulsory Romanian language examination for public administrators introduced in 1920 and subsequently, land confiscation, public education and religious legislation that affected Hungarians adversely. All this contributed to masses of people fleeing Romania for Hungary - by the end of 1920, 154,000 Hungarians had fled to the mother country. (Varga 1998, 163) While in the early years of the century, when Hungary was a monarchy, economically-motivated migration primarily described the destitute peasant class in Transylvania, the urban middle class and the intelligentsia now also joined the ranks of migrants. Of course, this was immigration in a different sense, since it was directed at what used to be the home country before the borders were redrawn.

The Transylvanist movement that emerged by the end of 1921 had somewhat slowed down the rate of migration but could not stem it completely, since between 1924 and 1940, another 169,000 people moved to Hungary. (Transylvanism was a movement which determined the existential world view of the Transylvanian Hungarians, advocating a return to historical roots, the preservation of a national self-identity and the acceptance of minority status.)

In 1940, the borders were revised again and Northern Transylvania became part of Hungary again until the end of World War II. Migration increased in this period: hundreds of thousands moved from Southern Transylvania (still under Romanian rule) to Northern Transylvania or to Hungary proper.

During the 1950s and 1960s, the severity of the Communist regime allowed few people to leave Romania, controlling migratory processes and discouraging migration on the policy level. However, there existed, from the 1970s on, "officially supported emigration" involving the Jewish and German (Saxon) minorities in Romania. In the case of both ethnicities, there were mother countries that not only accepted an unlimited number of them but actually paid the Romanian government for each and every migrant that was allowed to leave. Hungary, however, took no stand in the interest of Hungarians living outside the borders until the mid-1980s - wanting neither to encourage immigrants nor to accept a large number of them. 
After the end of the 1960s, the endeavors in Romania to forcefully assimilate minorities were increasingly visible and ethnic discrimination towards the Hungarian minority became ever more open. Along with the forced industrialization and urbanization efforts, a significant number of ethnic Romanians were settled into towns with a Hungarian majority, Hungarian graduates of universities were transferred to Romanian-populated areas and barred from returning to their homeland. After the late 1970s, there were signs of interest on the part of Hungarians in the mother country - primarily by the intelligentsia - to help Hungarians in Transylvania. Shipments of medicine and cultural goods were sent to Transylvania and because immigration was officially outlawed, there were a growing number of fake marriages, the triedand-true method of helping Transylvanians to settle in Hungary.

In the 1980s, the Romanian government carried out an increasingly anti-minority ethnic policy. The dismantlement of Hungarian-language education and cultural institutions was stepped up, the use of the Hungarian language was forbidden in institutions, and when referring to villages, towns and cities, only the use of their Romanian names was allowed. Plans to demolish entire Hungarian-populated villages to eradicate rural Hungarian traditions finally incited the Hungarian government to call international attention to the plight of Transylvanian Hungarians.

At that time not only was official emigration a near impossibility in Romania but so was simple travel as well: very few people received passports to travel even when travel meant going on a trip once every two years. Reception of foreign (especially Hungarian) visitors elicited repercussions and Hungarian cultural goods (books, journals, newspapers, etc) were often barred from entering the country.

The repression of migratory processes by the Communist regimes is well represented by the staggeringly low figure of 7,520 - this is how many Romanian citizens (mostly of Hungarian ethnicity) were naturalized in Hungary in the 30 years between 1958 and 1987 (Tóth 1997, 115).

\section{The latest waves of migration}

The latest wave of migration from Romania to Hungary was set off some 15 years ago at the end of the 1980s. Together with the conditions in Romania already spoken of, the 1980s also brought about a radical economic decline and a drop in the standard of living. Due to Romania's worsening economic situation and its ethnic policies, migration of ethnic Hungarians commenced again in the second half of the 1980s. Because of official constraints put on emigration, a great number of "tourists from Romania" applied in Hungary for asylum and refugee status and there was a significant increase in the number of illegal border crossings. All this was now helped 
by the Hungarian government which, tacitly at first but later openly, accepted and helped the refugees.

The number of Romanian refugees registered in Hungary was the highest between 1988 and 1990, comprising 87\% (47,954 persons) of all Romanian refugees registered by 2002 (Table 1). Half of the refugees from Romania crossed the borders illegally in 1988 , while this figure went up to $80 \%$ in the following year. At the same time, while $89 \%$ of the 1988 arrivals were of Hungarian ethnicity, this figure dropped to $62 \%$ in the following year (Tóth 1997, 49-50). This indicates that as a result of increasing repression and a growing economic crisis, the migration of ethnic Romanians had also commenced.

Of the 55,000 refugees landing in Hungary between 1988 and 2001, only 2,955 were granted refugee status by the Hungarian authorities. (Hungary became a signatory of the Geneva Convention on Refugees in 1989.) Most of the others presumably managed to obtain immigrant status and then citizenship and a fraction of them must have returned home.

Table 1. Romanian citizens registered as refugees and granted permanent refugee status in Hungary between 1988 and 2002.

\begin{tabular}{lrr}
\hline Year & Registered refugees & $\begin{array}{c}\text { Granted permanent } \\
\text { refugee status }\end{array}$ \\
\hline 1988 & 13173 & - \\
1989 & 17365 & 27 \\
1990 & 17416 & 2522 \\
1991 & 3728 & 255 \\
1992 & 844 & 79 \\
1993 & 548 & 26 \\
1994 & 661 & 17 \\
1995 & 523 & 14 \\
1996 & 350 & 2 \\
1997 & 131 & - \\
1998 & 124 & 1 \\
1999 & 16 & - \\
2000 & 36 & 2 \\
2001 & 76 & 10 \\
2002 & 15 & - \\
\hline
\end{tabular}

Source: The Immigration and Naturalization Bureau of the Ministry of Interior. (http://www.b-m.hu) 
Considering the issue of the number of immigrants to Hungary, its fluctuation from the early 1980s to the present reflects the commencement of migration and its subsequent intensity changes. Comparing the number of immigrants from Romania given by the Hungarian registers with the number of emigrants to Hungary registered by the Romanian authorities (Figure 1), we find that both registers have a similarly low number of migrants until 1986. The first signs of illegal emigration are visible in 1987.

From 1988 the intensity of migration increased radically and the difference between the two registers grew rapidly. Both registers reflect the fact that after long decades of harsh repression, migration from Romania to Hungary gathered momentum in the second half of the 1980s and both its legal and illegal forms had grown to a significant size by the end of the decade. (This illegal immigration did not amount to illegal border crossing in every case.)

Figure 1. The number of immigrants from Romania to Hungary in the registers of the two countries (1981 to 2001).

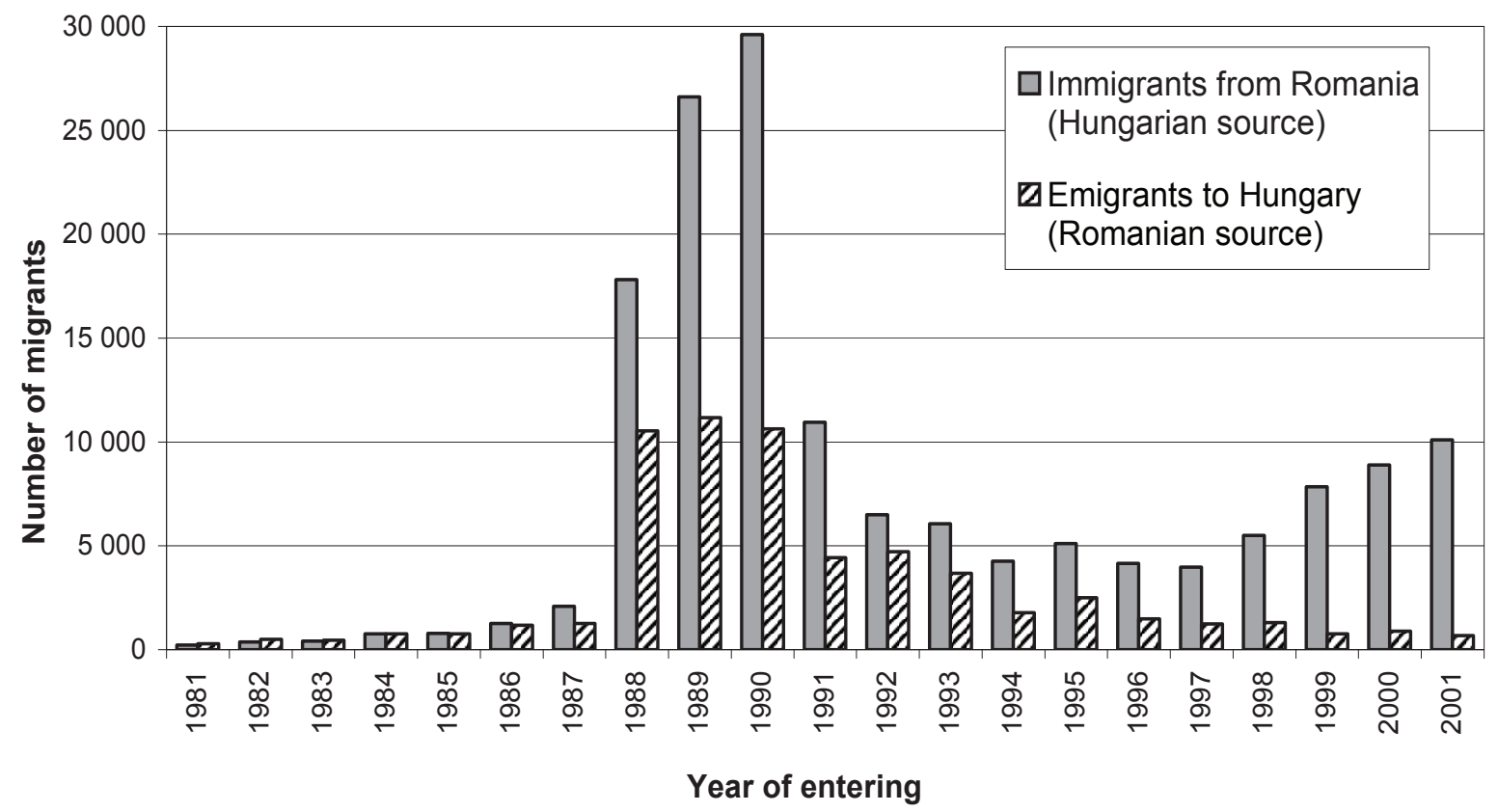

Source: Hungarian Yearbooks of Demography (preliminary data for 2001) and Romanian Statistical Yearbooks. 
The 1989 changes of the political regimes in Romania and Hungary resulted in radical changes in the migratory patterns between the two countries. Because getting a passport was no longer problematic in Romania, a lot of people left the country without reporting their intent to emigrate to the local authorities and only applied for a permit to settle when in the destination country. These people do not show up in official Romanian statistics as emigrants. This is the reason why the number of immigrants from Romania ${ }^{1}$ registered in Hungary continued to be higher throughout the 1990s than the number in the official Romanian statistics (Figure 1).

With the borders more permeable than before, the immigration context also changed for ethnic Hungarians in Transylvania: leaving one's homeland did not necessarily have to be preceded by the difficult decision to make a permanent and irreversible move, not even in those cases that ended in permanent settlements. A lot of people simply crossed the border without the intention to immigrate in order to take advantage of the growing employment and education opportunities in Hungary.

This brought about new forms of migration. Besides the immigrants, a lot of Romanian citizens appeared in Hungary as students in Hungarian institutions, or workers having a work permit or workers without a permit taking advantage of the 30-day visa-free stay. People belonging to this last group work mostly in the so-called "black economy". Because they are illegally employed, it is difficult to estimate their numbers. (Ágoston 1994)

With all the variety in the migratory processes, the number of Romanian immigrants to Hungary dropped spectacularly after the peak year of 1990. For a few years, the numbers stagnated at a relatively low level and then took a turn upwards after 1999 (Figure 1). (This is not borne out by Romanian statistics.) We can only assume either that the increasing figures indeed indicate an increasing volume of migrants or that a large number of people already living in Hungary tried to legalize their situation before the country's accession to the European Union.

However that may be, the growing number of applications both for immigration and for residence permits indicate that another wave was about to crest at the end of the 1990s (Table 2).

\footnotetext{
${ }^{1}$ Immigrant status is defined in Hungarian statistics as citizens of foreign countries in possession of an immigration permit or a permanent residence permit.
} 
Table 2. Immigration and residence permit applications submitted by Romanian citizens in Hungary (1994-2001)

\begin{tabular}{cccc}
\hline Year & $\begin{array}{c}\text { Immigration permit } \\
\text { applications }\end{array}$ & $\begin{array}{c}\text { Permanent residence } \\
\text { applications }\end{array}$ & $\begin{array}{c}\text { Temporary residence } \\
\text { applications }\end{array}$ \\
\hline 1994 & 4619 & 3528 & 20313 \\
1995 & 3126 & 6586 & 9688 \\
1996 & 3271 & 4366 & 5890 \\
1997 & 3224 & 5760 & 6428 \\
1998 & 3271 & 6216 & 7428 \\
1999 & 5266 & 8449 & 10125 \\
2000 & 5397 & 10626 & 13071 \\
2001 & 6093 & 12552 & 16944 \\
\hline
\end{tabular}

Source: National Police, Ministry of Interior (http://www.b-m.hu)

After January 1, 2002, immigration permits in Hungary have been replaced by the so-called "settlement permits" and residence permits were no longer divided into temporary (under 1 year) and permanent (over 1 year) permits. In the year 2002, Romanian citizens submitted 3,020 settlement permit applications and 16,048 residence permit applications to the Hungarian authorities, according to the Immigration and Naturalization Bureau of the Ministry of Interior. This constitutes a decrease from the number of applications submitted in the previous year. Whether this is only a temporary lull due to stricter administrative rules or whether this signals a turn in the trend, only the coming years will tell us.

Figure 2. Number of immigrants entering Hungary, by place of origin (1987-2001).

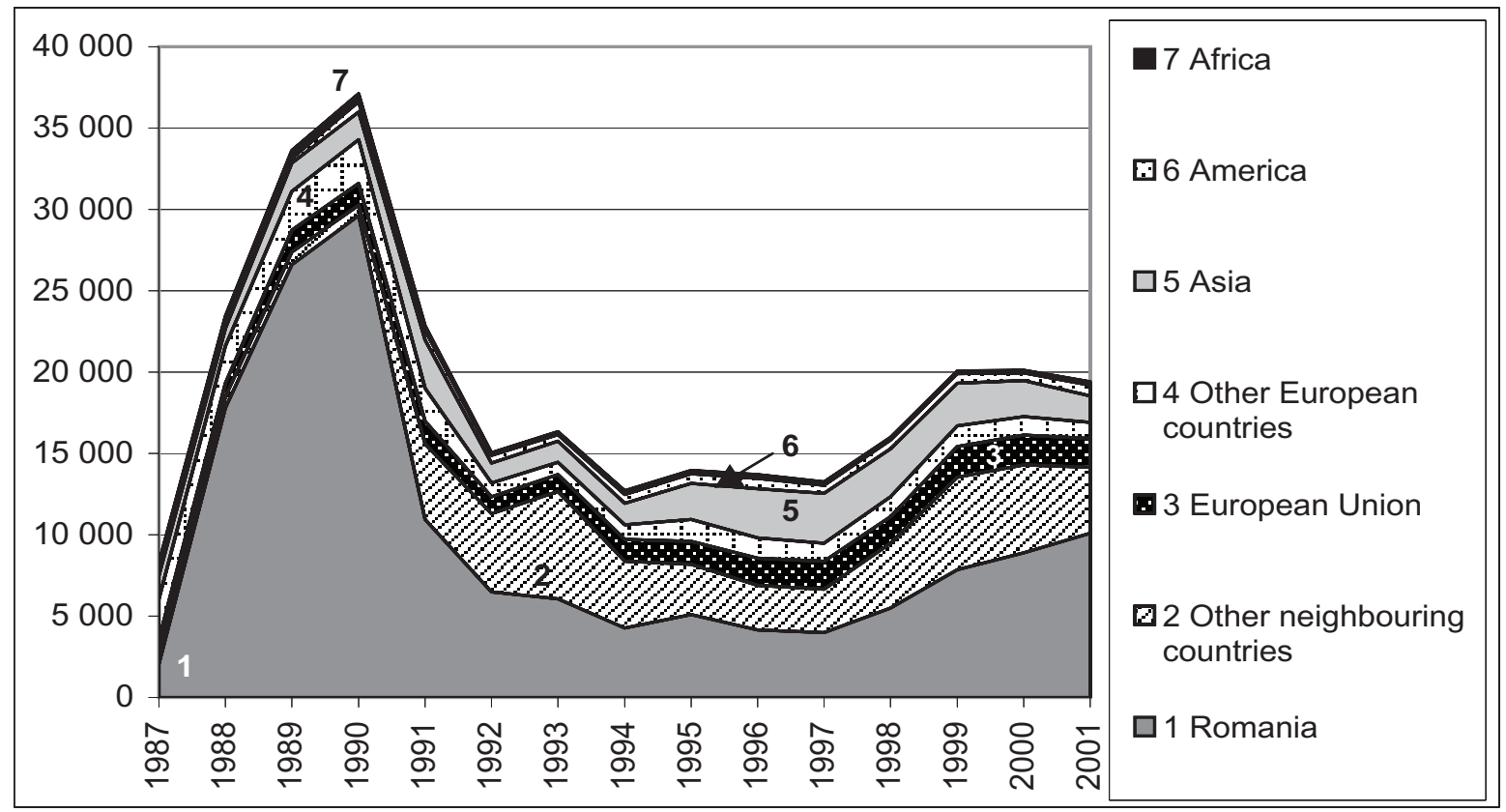

Source: Hungarian Yearbook of Demography (preliminary data for 2001) 
Figure 2 clearly shows that immigrants from Romania constitute the largest group of all immigrants entering Hungary. At the start of the migratory wave (between 1988 and 1990) their proportion was $75 \%$ to $80 \%$ but later both their number and proportion decreased - between 1993 and 1999 it was under 40\%. The past few years again saw an increase and in 2001, over half of all immigrants came from Romania.

The total number of immigrants from other neighboring countries (primarily from Slovakia, Ukraine and the former Yugoslavia) only reached the number of immigrants from Romania in the early 1990s, at the time of the Balkan Wars and, while we can observe a slight increase lately in the numbers of this group, Romanian immigrants continue to constitute the most significant group. Various studies concluded that in the 1990s, the proportion of ethnic Hungarians compared to all immigrants from Romania was $90 \%$ to $95 \%$. (Tóth 1997, Gödri 2003b)

An increase was not only observable in the number of immigrants but also in the number of people entering the country seeking employment. After 1999, the number of work permits granted to Romanian citizens in Hungary suddenly went on the increase (Figure 3). (Those in possession of immigration permits need no separate work permit to gain employment.) Some $80 \%$ to $90 \%$ of all Romanian citizens granted work permits were ethnic Hungarians.

Figure 3. The number of work permits granted to Romanian citizens in Hungary (1994 to 2002).

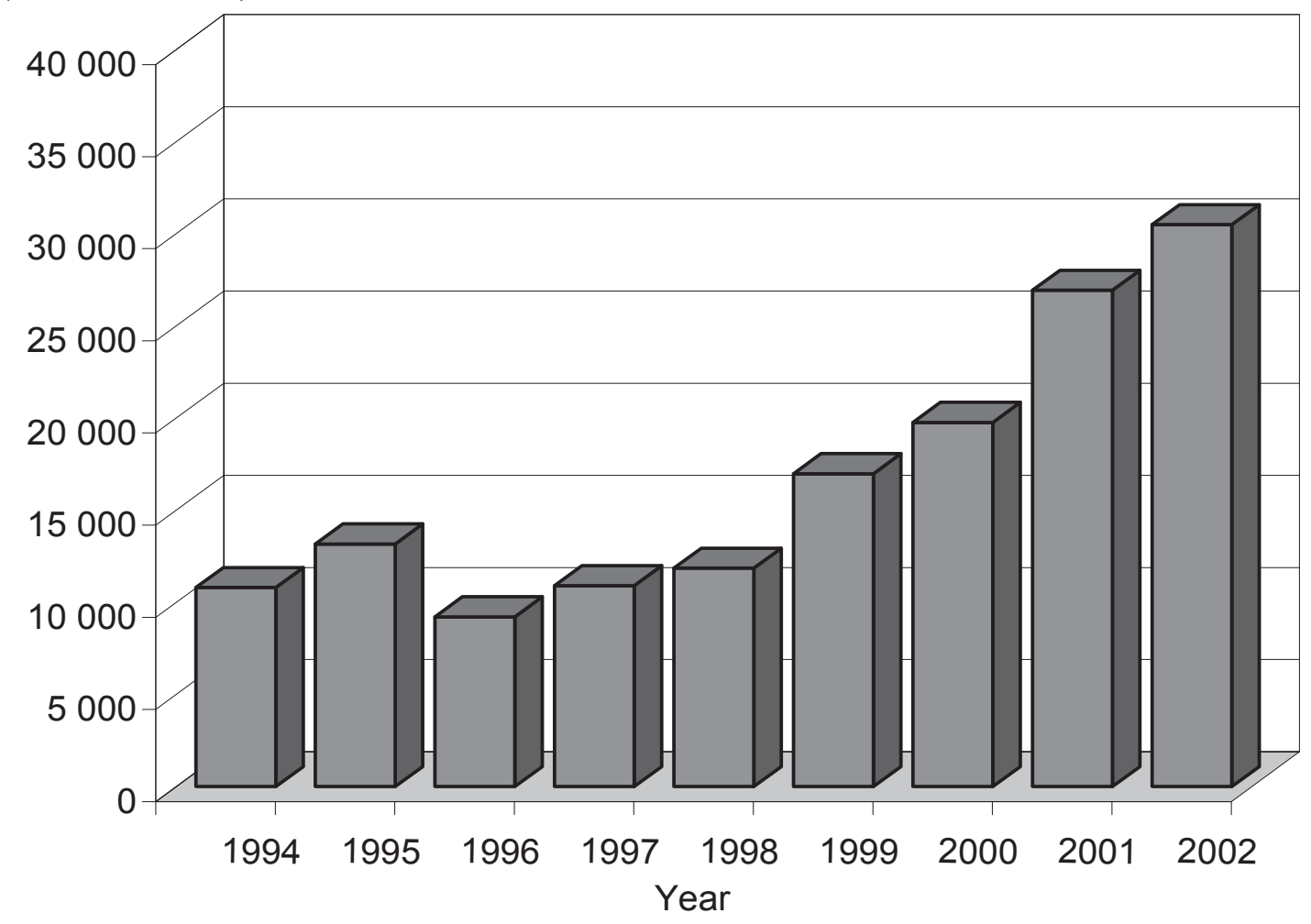

Source: Bureau of Employment 
In the early $1990 \mathrm{~s}, 70 \%$ of all work permits were issued to Romanian citizens. After 1992 , this proportion dropped somewhat and stagnated around $40 \%$ to $50 \%$ until the end of the decade. Then, it swung upward again, reaching $61 \%$ by 2002 . This is partly due to the fact that in spite of the political changes in Romania, the country's economy still suffers and a large part of the population is finding it difficult to make ends meet and unemployment is also a significant threat. For the ethnic Hungarians in Romania, the most obvious strategy is entering the labor market in Hungary for reasons of proximity and no language difficulties.

With regards to Hungary's accession to the European Union on 1 May 2004, one may justly wonder whether there will be any changes - negative or positive - impacting the migration processes of Hungarians living in neighboring countries. ${ }^{2}$ A survey carried out at the end of 2002 among Hungarians living in surrounding countries, measuring their migration potential, identified Transylvania and the Subcarpathian region in Ukraine as the two regions with the greatest "threat" of migration (Örkény 2003). According to the study, $45 \%$ of the ethnic Hungarians in Transylvania are planning a short-term employment stay, while $29 \%$ of them were thinking of longterm employment stays and $23 \%$ of migrating definitely. Hungary remains a primary target for them: $38 \%$ of the respondents were planning their short-term employment stay to take place in Hungary, 22\% wanted to be employed long-term in Hungary and $17 \%$ of them wanted to migrate for life to Hungary.

The intent to migrate is especially high among young people and the intelligentsia. The strongest determinant of the intent to seek work abroad is unemployment: mostly unemployed young people living in substandard financial circumstances plan to seek employment abroad. (Örkény 2003) The extent to which these plans will or will not be realized also depends on Hungary's policies on migration.

\section{The socio-demographic composition of the immigrants}

The composition of the people entering Hungary with a view to settle is an essential issue for Hungary, just like for the countries of origin of the migrants. In the case of the ethnic Hungarians in Transylvania, the issue is a loaded one, because the rate of migration is a significant factor in the decrease of the ethnic Hungarian population. Between the last two censuses, the Hungarian population in Romania dropped by 193,000 and most of this decline (some experts say two thirds) is due to migration. The effect can be exacerbated if most of those leaving were of reproductive age.

\footnotetext{
2 Romania may be able to join the EU in 2007 under the best of circumstances.

3

3 The second most popular destination country was Germany, though only for purposes of employment - only $3 \%$ would migrate definitely to Germany.
} 
In the following, we will review some socio-demographic features (gender, age, economic activity, occupation) of the immigrants coming from Romania to Hungary from the late 1980s to the present, using the database of the Central Statistics Office, compiled on the basis of the registers of the Immigration and Naturalization Bureau of the Ministry of Interior.

Looking at the gender distribution of the immigrants, we find that among those arriving in 1988-1989, men were in a majority (60-63\%), suggesting that men under those circumstances were more likely to assume the risks of crossing the border, while after 1990, the gender ratio is well-balanced each year.

The age distribution of immigrants reflects one of the important phenomena of the immigration process of the last decade. While between 1988 and 1991, the dominant age groups were the 20- and 30-year-olds with a significant portion of those under 20 , the proportion of over-50-year-olds was negligible (4\% to $6 \%$ ). After 1992, the proportion of immigrants in their 20 s continued to be the highest, while the proportion of older immigrants started to increase. (Figure 4)

Figure 4. Age distribution of immigrants (1988-2001).

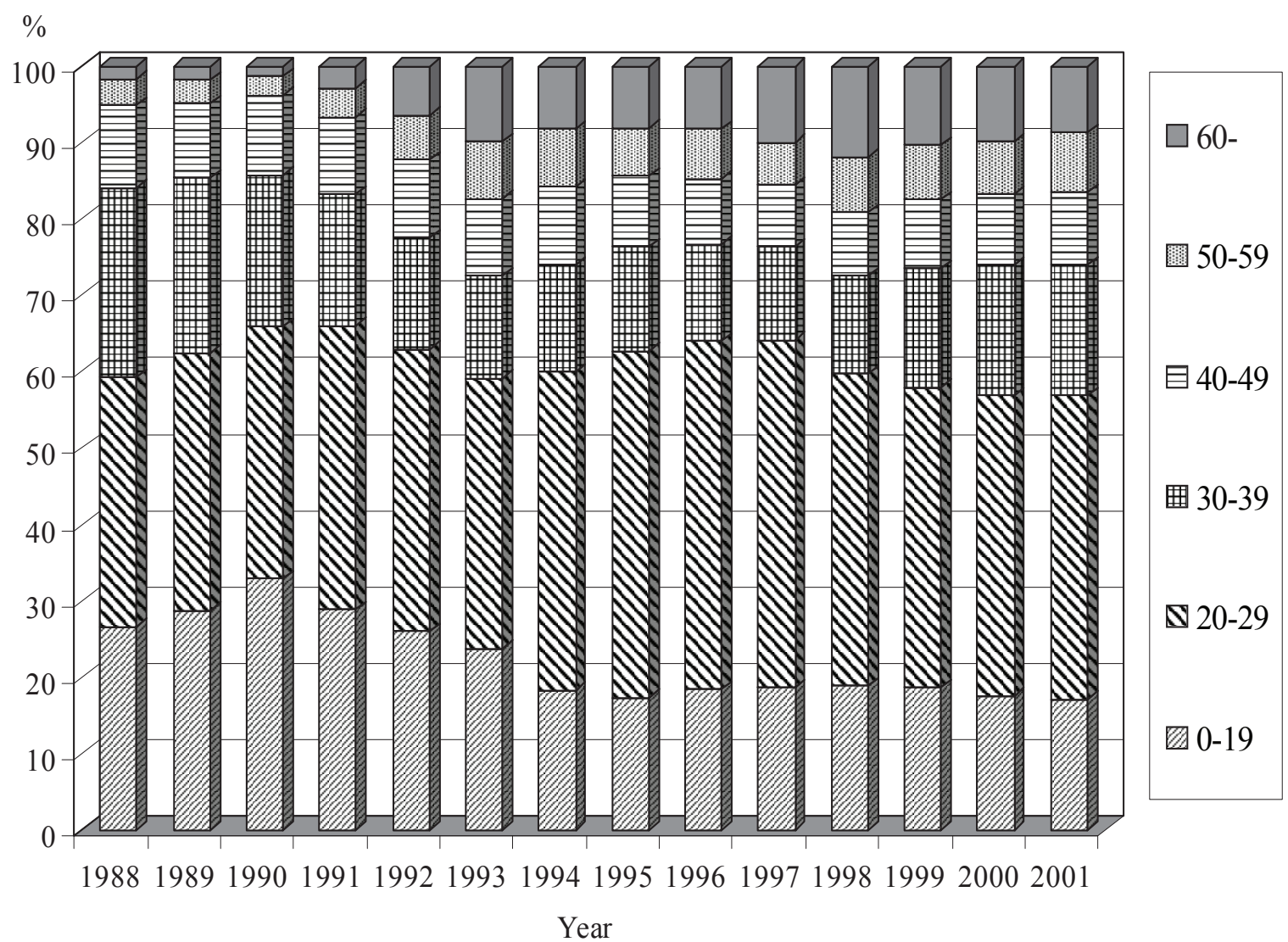


This change in the age composition of the immigrants is attributable to the phenomenon that, as a consequence of the primary migration to Hungary in the late 1980s and early 1990s, a pattern of secondary migration commenced, primarily in the form of family reunifications. Most of this is parents moving to live with the younger generation who had settled in Hungary earlier, and this is why the proportion of the older age groups is rising.

The level of education of immigrants constitutes an important category - especially as there are concerns among Hungarians in Transylvania over the number of young people and intellectuals leaving their homeland - unfortunately the relevant statistical data is full of holes. However after 1990, the economic activity of the immigrants has been registered and, in the case of those economically active, their occupation as well.

Regarding economic activity, we have observed that while in the first two years of the 1990s, some two thirds of the immigrants were employed and 30\% of them were students, after 1992, the categories of "unemployed" and "homemaker" - which are not always easy to distinguish - make an appearance. After 1995, the proportion of pensioners becomes more significant (15.6\% in 2001). (Figure 5). This is also a marked sign of the secondary migration already mentioned.

Figure 5. The distribution of immigrants according to economic activity (1990 to 2001).

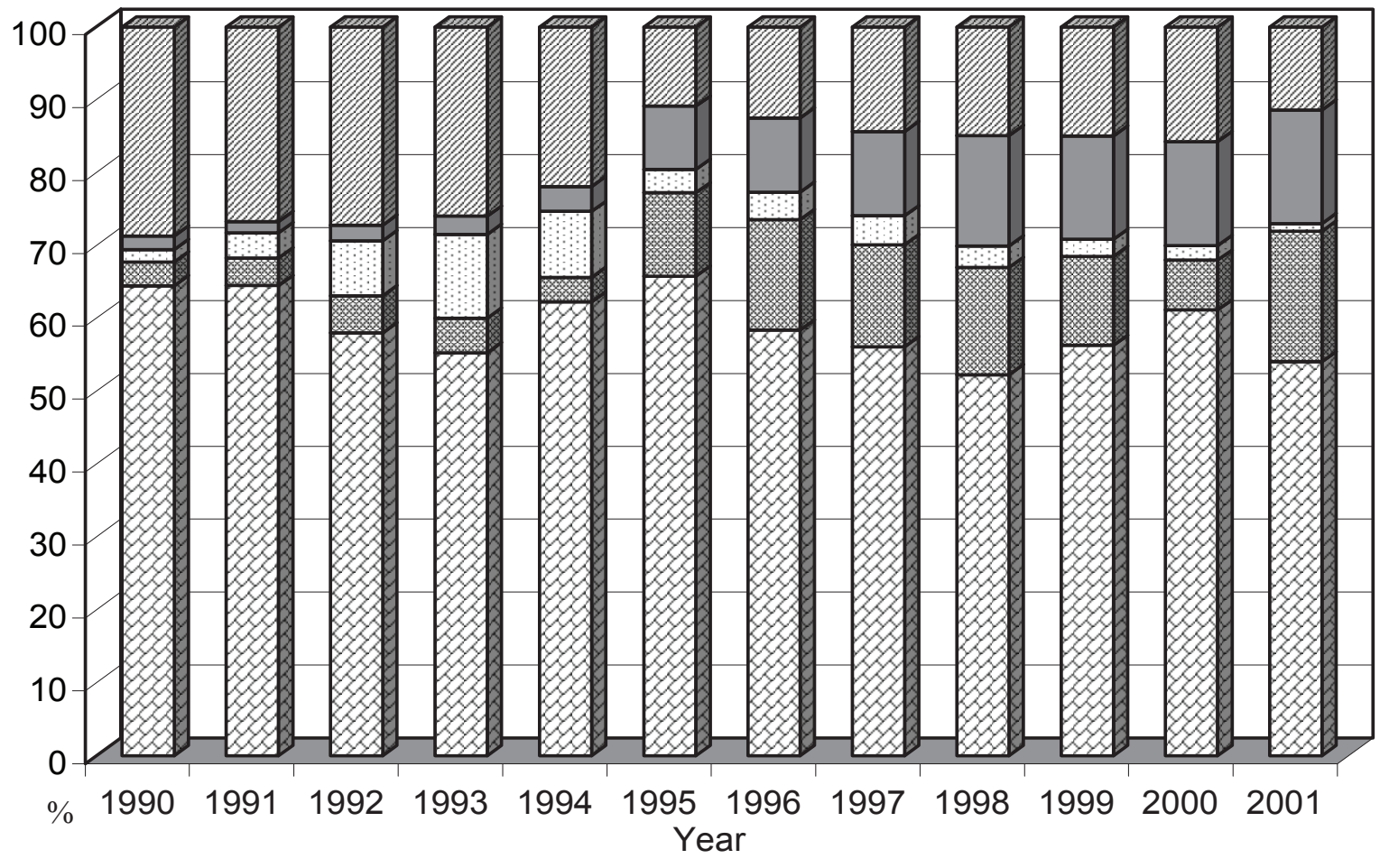

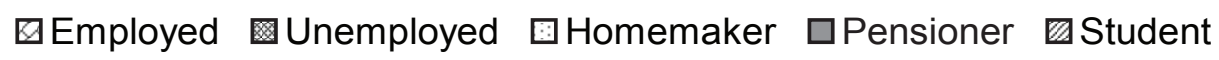


The occupation distribution of the employed shows that the largest group is composed of skilled laborers (more specifically those working in construction and industry): their proportion was around $45 \%$ in 1996 when it started to decline and dropped below the low point of 35\% in 1998-1999 - but by 2001, the proportion was back at 45\%. (Figure 6) The proportion of white-collar workers (administrative and service industry employment) fluctuated mostly between $25 \%$ and $30 \%$, with the exception of 1998-1999, when the proportion almost reached 35\%. The proportion of people employed in jobs requiring college or university degrees was between $14 \%$ and 17\% until 1998 and gathered some momentum around the turn of the millennium $(18 \%-19 \%)$. (This is presumably a lowest value for the true proportion of higher educated people, as there is no way of telling how many of these people were forced to accept, either prior to or after immigration, jobs requiring lower qualifications.)

Figure 6. Occupation distribution of immigrants (1990 to 2001).

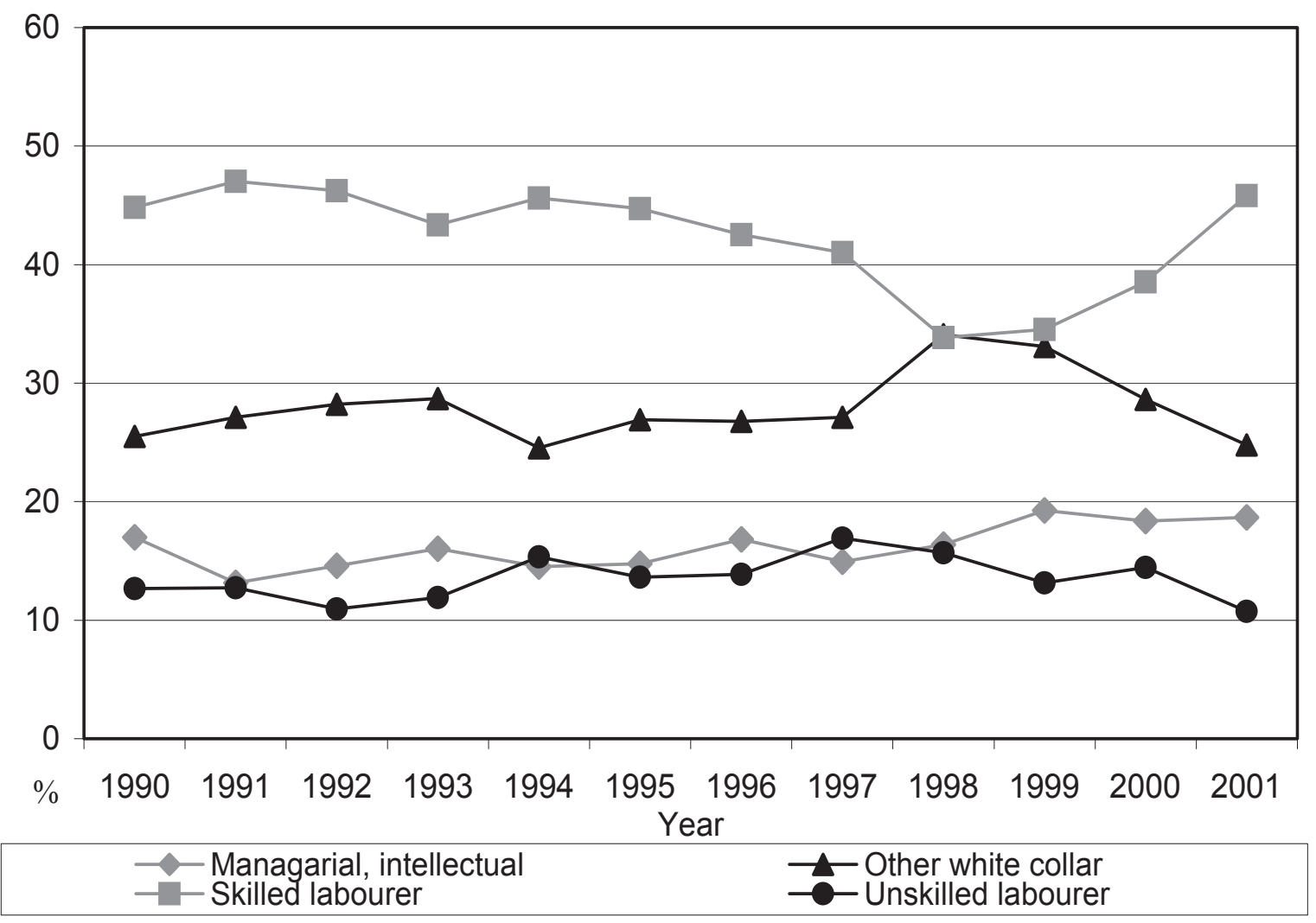

Source: Central Statistical Office of Hungary 


\section{Selection of migrants from the population of origin}

Migration is mostly a selective process in the course of which mostly people with greater "human capital" (younger, better educated, more skilled) leave their original communities. With the establishment of migrant networks, however, migration becomes increasingly independent of those factors which had set it off and becomes less selective. (Massey et al. 1993)

What selection processes have been at work in the migration processes in our analysis? What groups exhibit an above-average propensity for migration? What are the regions, settlement types and ethnic environments that are more permissive of emigration?

Since statistical registers contain a limited number of features describing the entire group of immigrants, we had to have recourse to the results of a questionnaire-based survey. This representative survey - as a part of a larger research project ${ }^{4}-$ was carried out in the summer of 2002 and comprises a sample of 1,015 persons (over eighteen) who came from the neighboring countries and gained immigrant status in Hungary in 2001.

We have already seen that the surplus of males, recorded at the end of the 1980s and attributed to the conditions of immigration and the attendant uncertainties and risks - was no longer observable in the 1990s, and therefore we cannot speak of selection on a gender basis.

The age distribution of the immigrants, however, shows remarkable differences from the age structures of the Hungarian population in Transylvania. Even though there is some indication of increased participation of older age groups in migration - at the start of the migratory wave, $85 \%$ of the migrants were under 40 , while today this is true for "only" $73-74 \%$ of them - the proportion of the people in their 20 s within the entire migrant population is two to three times their proportion within the population of origin. To illustrate this, let us look at the age group distribution of immigrants in a gender breakdown, comparing it with the age group distribution of the population of origin (Figure 7).

${ }^{4}$ Research project NKFP 5/0084/2002 
Figure 7. Age distribution in gender breakdown of Hungarians in Transylvania (Census 2002) and of people granted immigrant status in Hungary in 2001.

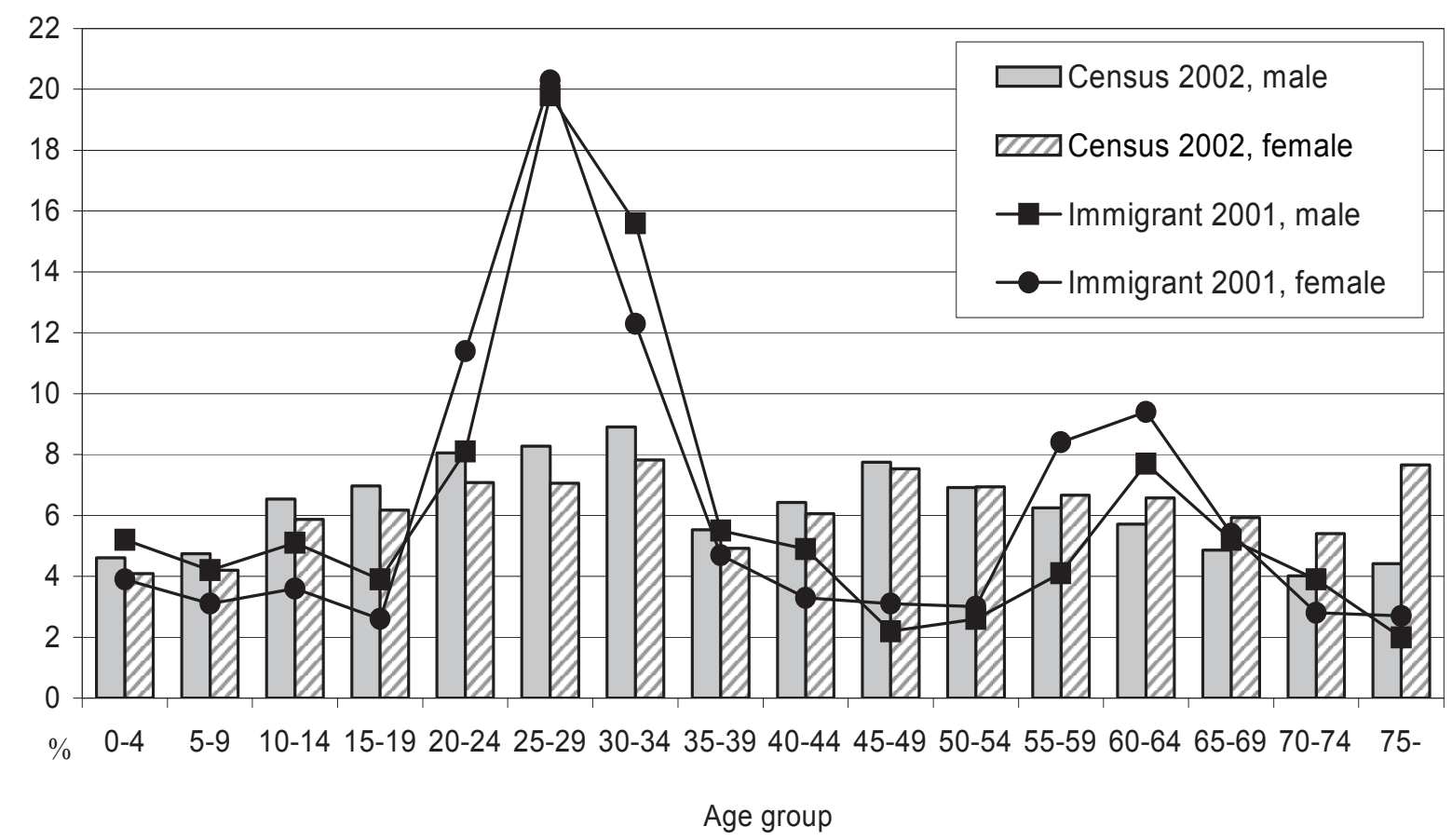

Source: Census in Romania; Survey data

It is rather clear that migration is age-specific: the 20-34-year-olds among females and the 25-34-year-olds are radically overrepresented among the migrants. An attendant consequence of this, however, is that besides directly depleting the size of the community of origin, migration exerts an indirect influence on the population size, speeding up the decrease of natural reproduction. In all probability, this phenomena has played a role in the decreasing fertility of Hungarians in Transylvania.

Besides the conspicuous peak of young people, we can discern another, albeit more modest one, that of the older generations, and more emphasized in the case of women. This indicates that besides young people just entering the labor market or still in school, older people just entering pensioner age also migrate more frequently.

From the perspective of completed education levels, the difference between the immigrants and the population of origin is also significant. According to an earlier study (Tóth 1997), among immigrants from Romania who submitted citizenship applications in 1993, 26\% had a higher education degree. Among those who gained immigrant status in 2001 the proportion of higher educated people was $25.5 \%$. On the other hand according to the Romanian census of 1992 , only $4.2 \%$ of ethnic Hungarians over 20 had a higher education degree ${ }^{5}$. Even though the number of

5 Author's calculations based on data provided by Varga (1998) 
those with a higher education has been increasing since then, their proportion among the over-20 population is presumably far behind their proportion in the immigrant population.

We arrive at a similar picture if we look at the occupation distribution among the active population. The proportion of managers and intellectuals was $5.7 \%$ in the population of origin in 1992 (Varga 1998, 274) while, as we have seen, their proportion was around $14 \%-17 \%$ in the 1990 s among the immigrants to Hungary, and has actually exceeded $18 \%$ in recent years. So from the point of view of occupation, the better-trained and skilled people are overrepresented among the immigrants when compared with their proportion in the population of origin.

The territorial distribution of Hungarians in Transylvania is uneven. In two counties, they constitute a majority of about $74 \%$ to $85 \%$, while in four other counties, they constitute a sizeable minority between $20 \%$ and $40 \%$. Their proportion is lower than this in the ten other counties. If we look at those who gained immigrant status in 2001 by the county of origin (Figure 8), we find that immigrants come in smaller proportions both from Southern Transylvania (where Hungarians constitute some $11 \%$ of the county population) and from the two counties with Hungarian majorities than their proportion of the distribution within Romania.

Figure 8. Territorial distribution by counties of origin of Hungarians in Transylvania and those who were granted immigrant status in 2001 in Hungary.

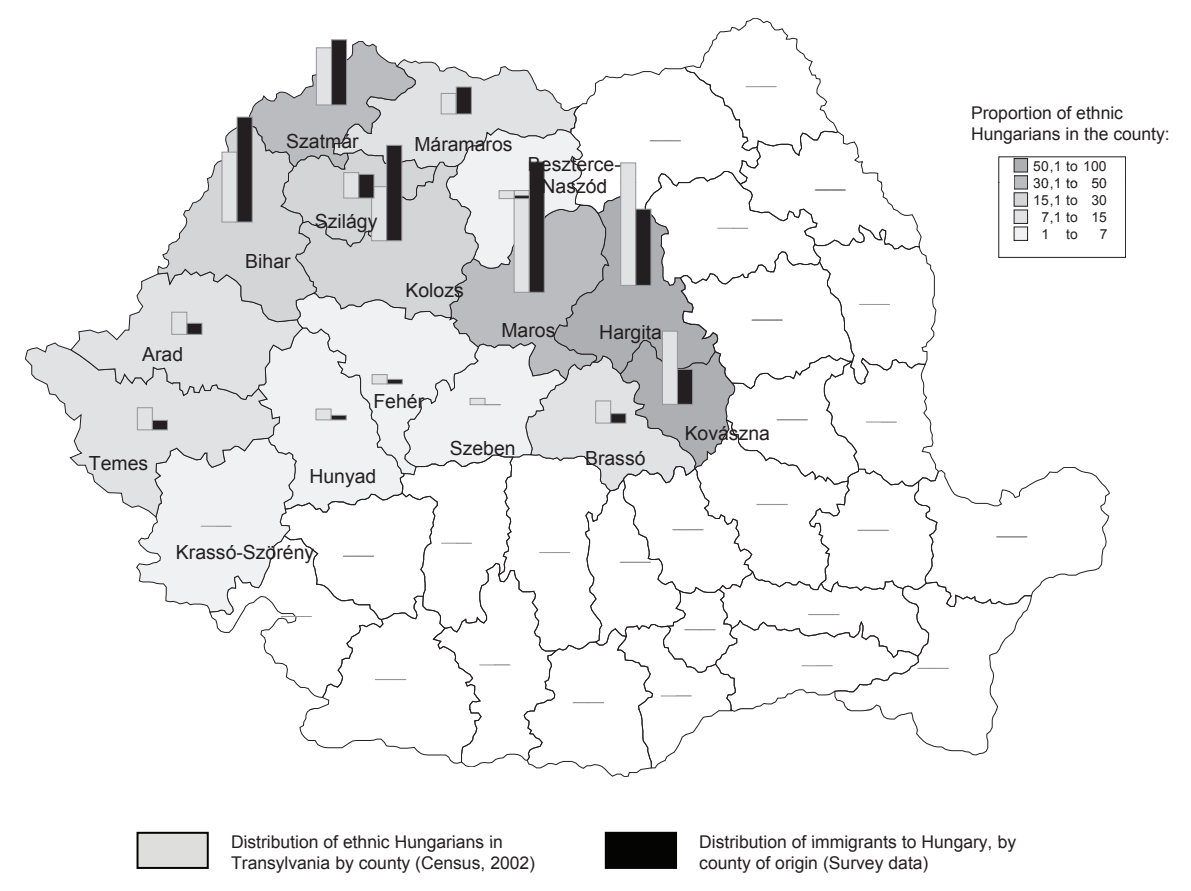


The explanation probably has to do with migratory patterns that are less widespread among those living in Southern Transylvania (who constitute small minorities). Ethnic Hungarians in these areas are more integrated into the Romanian society and Hungary is less of a point of reference from them. These of course are but hypotheses - further studies need to be carried out among the Hungarians living in these areas to prove them.

The reason why emigration from areas heavily populated by Hungarians seems subdued is probably manifold. On the one hand, the retaining power of ethnically homogenous communities is greater, as pointed out in studies of migratory potential (Simonovits 2003). On the other hand, we need to keep in mind that in these two counties the most common migratory strategy is that of guest work (Bodó 1996).

A look at settlement types will reveal that the urban environment is more conducive to migration than the rural one. According to the 2002 census, $55 \%$ of Hungarians in Romania live in urban environments - but a look at last place of residence of immigrants yields a much greater percentage (80\%) and if the place of upbringing is taken into account, the proportion is still at $68 \%$. (This might indicate that in the case of those who grew up in a rural environment, emigration was preceded by internal migration: $45 \%$ of them had left their villages and $75 \%$ of those who left moved to cities.) Differences according to settlement types are probably also attributable to the fact that Hungarians who live in a rural environment are more likely to live in an ethnically homogenous environment or at least in Hungarian-majority areas.

\section{Causes of migration and individual motivations}

\section{General considerations}

In order to be able to understand the causes of the migratory processes, we have to take into consideration all those social, economical and political circumstances which gave rise to them, and which were observed all throughout the 1990s. We also need to keep in mind that both the population of origin and that of the destination country belong to the same ethnicity, so the migrants were not going to a "foreign country," but in most cases, to a country that they regarded as their true homeland.

The circumstances in Romania suggest that different causes motivated those who left in the 1988-1989 migratory wave than those that made people leave in the 1990s. A questionnaire-based survey among the 1988 refugees concluded that the primary cause for immigration was the hopelessness of the political and economical situation in Romania, though many cited insults and injuries suffered because of their ethnicity as well as ethnic discrimination (Sik 1990). 
In the first years after the 1989 change of the political regime, for many immigrants the causes for leaving went back to the social-political conditions of the previous years, while at the same time, the opening of the borders presented an opportunity long desired and planned for (Gödri 1998).

The 1990s brought about significant changes for Romania and Hungary, both in politics and economics. The transition to a market economy did not take place at the same pace in the two countries. While Hungary produced relatively significant economic growth in the decade after the change of regime, in Romania the restructuring of the economy was not successful and the inner reserves of the economy were exhausted by 1997, giving rise to significant financial and social tensions. By the end of the millennium, there was a significant gap between Hungary and Romania with regards to their economies as measured by the per capita GDP, inflation, wages and unemployment.

A number of theories expounding the causes of international migration stress the role of economic factors underlying the importance of various elements. The earliest theory, that of Ravenstein's classical migration theory using the push-pull model, regards the poor political and economical situation of the source country and the attractions of the relative advantages of the destination country as the engine of international migration. The neoclassical economic theory traces the origins of international migration back to country differences in wages and employment levels and points out the role of human capital (education, skills, languages) as well. (Massey et al., 1993). The development or modernization theory also interprets migration as movement from the less developed to the more developed countries and sees as its primary cause the poverty, unemployment and economic stagnation in the source country.

The economic differences between Romania and Hungary that manifest themselves on the level of the individual in tangible differences in wages and living standards and in some cases in unemployment, poverty and hopelessness, must in all probability have contributed to setting off and enlarging migration.

While economic difficulties impacted the entire population of Romania, the migrants to Hungary in the 1990 s were primarily of Hungarian ethnicity ${ }^{6}$. It is obvious that the ethnic element plays an important part in this migratory process. The role of ethnicity manifests itself in a number of ways. On the one hand, the cultural attraction of the "mother country" with its a better economic situation and geographical proximity is a given. It is undeniable that in this migratory process, the shared language and

\footnotetext{
6 There was emigration from the Romanian population as well, but their primary destination countries were the U.S., Germany, Canada and Italy.
} 
culture constitute significant symbolic capital which defrays the costs of migration and integration.

Historical and cultural ties all over Europe function as important catalysts for migration as these have helped bring about "privileged migratory ties between certain source and destination countries" (Münz 1998). The world systems theory - which sees international migration as the product of an increasingly globalized market economy - also emphasizes the historical ties between the source and destination countries since these amount to cultural and linguistic ties, making migration an easier process.

Besides having the same language and culture, Hungarians in Transylvania also look at the mother country as a model, an economic, cultural and lifestyle reference point. The consciousness of "belonging to the same nation" creates an image of the mother country which makes them see their movement not as migration but as a return to their homeland.

At the same time, the role of ethnicity is apparent in that it constitutes significant network capital for the migrants. Due to historical background, the same ethnicity and mother tongue, there were significant cross-border networks of relationships between Hungarians in Romania and the mother country even before the first larger migratory movements. These networks had an important role in setting off the migratory wave primarily motivated by political and economic causes. In the wake of the initial large wave (and also because of the increasing permeability of the borders after the change of regime), these networks gathered strength and were enlarged by the relationships of the immigrants and those who stayed in Romania, all of which facilitated further migrations. According to the social network theory, migration networks determine migratory decisions to a greater extent than do economic differences as they lower the risks and costs of migration. This makes network ties a form of social capital. (Massey et al. 1993). Therefore we can say that ethnicity appears in this process as important network and cultural capital and assumes a regulating and stimulating role (Brubaker 1998).

On the other hand, ethnicity also appears as a push factor: ethnic discrimination experienced in the homeland (which was more pronounced prior to 1989) as well as ethnic conflicts and tensions (which did not cease in Romania after the change of regime and occur in politics as well as in everyday life ${ }^{7}$ ) contribute towards regarding the future as hopeless or uncertain and towards the rejection of minority existence. 7 One of the most serious nationalist incidents in Romania took place in 1990 in Tirgu Mures (Maros-
vásárhely) when ethnic Romanians and ethnic Hungarians clashed openly. 
All these characteristics cannot be overlooked when studying the causes of migration. Another important question is how the immigrants themselves perceive the motivations that played a part in their decision (whether economic or ethnic motivations are primary) and the purposes for moving to Hungary.

\section{The purposes and motivations of immigrants on the basis of survey data}

A questionnaire-based survey carried out among those who were granted immigrant status in Hungary in 2001 revealed a number of novel aspects of the turn-of-themillennium migration of the Transylvanian Hungarians. (Among immigrants from Romania, 95\% were of Hungarian ethnicity, while the rest were German and a very small percentage Romanian. The majority of respondents arrived in Hungary in 2000 , but $20 \%$ of them entered the country prior to 1997 . (For details, see Gödri 2003b)).

The results of the study revealed that almost $25 \%$ of the immigrants (35\% of those younger than 35) were not intending to settle permanently but were motivated by temporary employment or continuing their studies. This indicates that the one-time event character that described the migration of the citizens of socialist states prior to 1990 is no longer applicable. The end-of-the-millennium characteristic of the European migratory processes - namely that the concepts of temporary and permanent migration are no longer sharply divided and the process of permanent migration usually takes place in a number of stages (Salt 2001) - also describes Hungary.

Temporary migration - carried out with the purpose of studying or working - is quite often a first, preparatory stage of final migration, since the chances for returning to the country of origin decrease with time, with the formation of personal and professional ties. (Gödri 2002)

The closed question (composed of a number of items) employed to reveal the migration motivations on the level of the individual, provided us with an opportunity to compare our data with the findings of an earlier study and thus illustrating the temporal changes in migration motivations. The earlier study was done among immigrants who submitted citizenship applications in 1993 (Tóth 1997) and most of them arrived to Hungary with the great migratory wave around 1990. 
Figure 9. The migratory motivations of immigrants to Hungary in 1993 and 2001

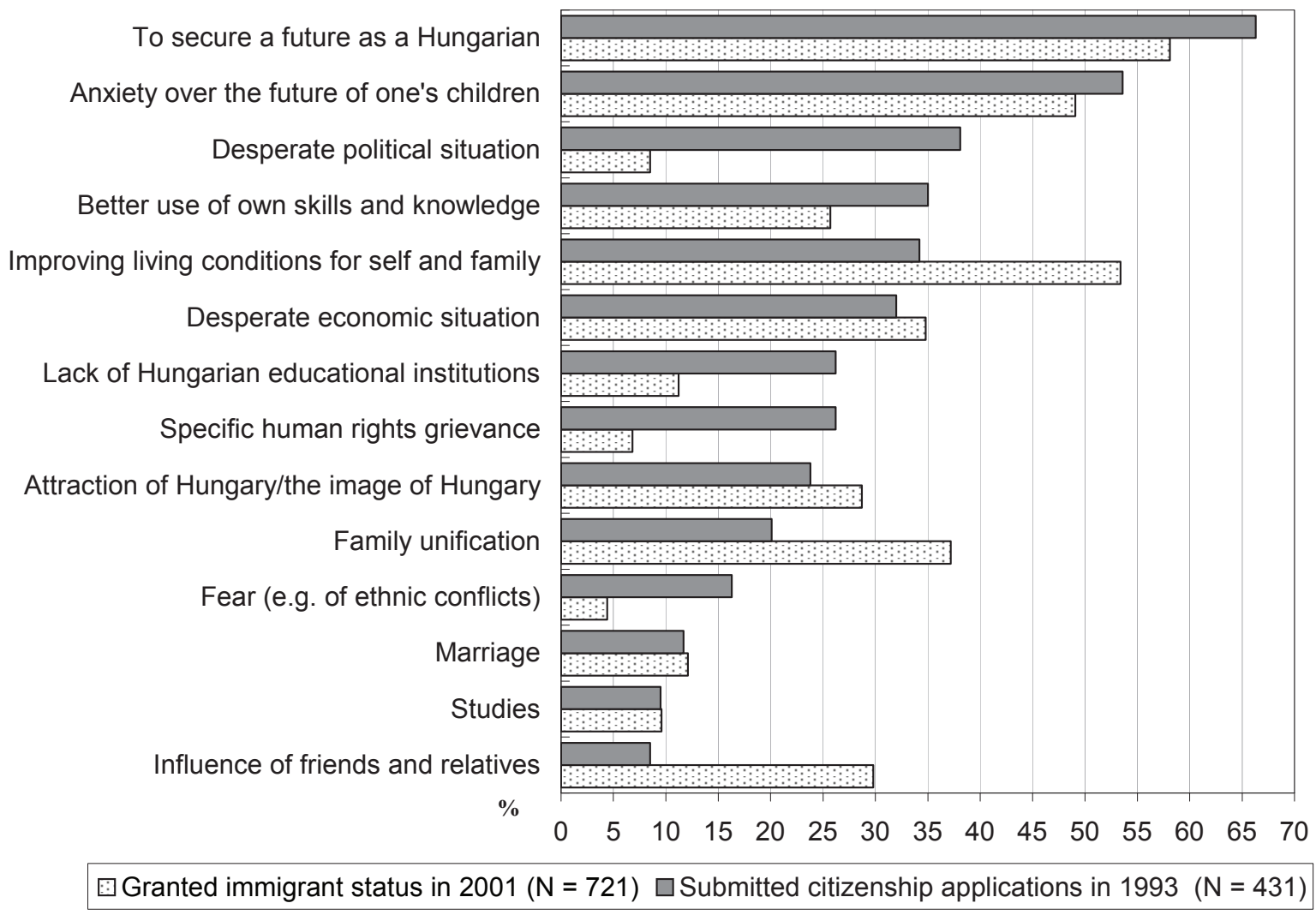

Source: Survey data

As we can see in Figure 9, most of the immigrants, both the recent and the earlier ones, cited worries about the future as their migratory motivation most frequently. This suggests that it is not just the present, the inferior economic conditions in Romania compared to Hungary, but the future, its hopelessness, that motivates people to migrate. It is conspicuous that motivations of an economic kind have come to the forefront recently: over $50 \%$ of the respondents cited the desire to improve their life conditions as a motivation and, somewhat more than earlier, people mentioned the desperate economic situation.

A greater proportion of economic motivations is found among younger people. They are the ones most impacted by the high unemployment in Romania $(9.8 \%$ of them were unemployed prior to migration and $24 \%$ of them in the last ten years) and they hope for an improvement in their economic standing and life conditions after migrating.

The results confirm the role of ethnic identity in migratory decisions. The most often voiced anxiety over the future ("to secure a future as a Hungarian") can also be seen as primarily economically motivated, but it also indicates that the respondents associated their minority status with a sense of an uncertain future ("as Hungarians," 
i.e. as minorities, they saw no chance for an improvement in their situation.) This is supported by the fact that one third of the respondents cited the wish "not to live in a minority" as a migratory motivation, rejecting minority status. Romania's minority policies and the ethnic discrimination experienced in the homeland might also have a role to play.

Compared to the earlier findings, there is conspicuous growth in the response frequencies of family unification and the influence of relatives, friends. This latter supports the notion that the significance of the network of connections is getting greater and it makes us conclude that this factor, if not a direct cause, is at least an important incentive to migration. Family unification was a motivation mentioned primarily by elderly people ( $80 \%$ of the respondents over 55$)$, which confirms the earlier mentioned fact that they constitute the majority of secondary migration.

The role of the networks can be seen not only in the migratory motivations of the migrants (mention of the influence of friends and relatives), but also in the attitudes regarding migration in the micro-environment, the proliferation of the migratory pattern and the network resources helping migration.

The acceptance of or perhaps support for migration as a long-term or medium-term life strategy within the community may increase the probability of the emerging of migratory plans. Where migration in any of its forms meets with "social approval", it is much more likely to spread. The reaction from the micro-environment experienced by the migrants was rather positive: two thirds seemed to be supportive of migratory intents, while $28 \%$ were understanding though sorry to see the migrants go. All in all, migration was an accepted and supported activity in the source communities and this must have been an important incentive for the migrants.

The network of relationships also played an important part in the mediation of the migratory pattern. As we know, migration is more likely to be the action of choice for those in whose network of relationships some people had already gained migratory experience or are currently living abroad (Massey et al. 2001). The closer these ties encouraging migration, the higher the chances for migration - therefore the influence of family relationships has a lasting impact on migratory processes (Fawcett 1989). Over half of the respondents (51\%) already had a family member settle in Hungary - in most of the cases, this family member provided the direct link for the migration of the respondents - and a significant portion of them had a friend, relative or acquaintance already settled in Hungary.

We know that the network of personal ties is a significant resource (it provides information, informs of opportunities, helps tide over the initial difficulties) and constitutes a form of social capital (Boyd 1989; Fawcett 1989; Massey et al. 2001). 
Besides the people who migrated earlier, personal ties originating in Hungary also played a helping role. Our study has confirmed that the immigrants were part of an extensive cross-border network of connections even before they migrated: only $13.6 \%$ of them had no family member, relative or friend in Hungary (migrant or native).

As for migratory motivations, there are quite serious downturns in many of the response categories (Figure 9). For the turn-of-the-millennium migrants, the desperate political situation in Romania was not as great an incentive as it was for the migrants of the early 1990s. Related issues - such as ethnic conflicts, human rights violations and lack of Hungarian educational institutions - were also less frequently mentioned. All this reflects the political changes in Romania, the fact that a process of democratization has, albeit reluctantly and hesitantly, commenced, the political stage is secured for the representation of the Hungarians in Romania and Hungarian language instruction has somewhat gathered momentum as well. However, even if fear on ethnic grounds seemed to constitute a migratory motivation for a limited number of people, $43 \%$ of the respondents confirmed that they have been negatively discriminated against in their homeland on ethnic grounds.

\section{Immigrant types}

We have already seen that even though certain outstanding motivations exist, the factors encouraging migration cannot be squeezed into a few groups but run the gamut of reasons. It is also noticeable that the available response choices represent different types of migration motives (e.g. a number of responses reflect economic motivations.) The question is whether there are distinctive groups among migrants with different motivations in the forefront. Applying the method of cluster analysis ${ }^{8}$, four immigrant types arise on the basis of migratory motivations. (Table 3.)

One large group is that of the economic migrants, comprising $29.2 \%$ of the respondents. Besides the anxiety over their and their children's future $(83.3 \%$ of the respondents), their migration was motivated by the desire to improve their living conditions ( $76 \%$ cited this reason). At the same time, the hopelessness of Romania's economic situation was mentioned at an above-the-average frequency (53.8\%) and many cited their "circumstances at home" which in the majority of cases referred to unemployment.

${ }^{8}$ We used the twostep clustering method of the SPSS package. 
Table 3. Immigrant types on the basis of migratory motivations.

\begin{tabular}{lrrrrr}
\hline & \multicolumn{5}{c}{ Immigrant types } \\
\cline { 2 - 6 } Motivation of migration & $\begin{array}{c}\text { Ethnic } \\
\text { migrant }\end{array}$ & $\begin{array}{c}\text { Career } \\
\text { migrant }\end{array}$ & $\begin{array}{c}\text { Economic } \\
\text { migrant }\end{array}$ & $\begin{array}{c}\text { Family } \\
\text { unificator }\end{array}$ & All \\
\hline To secure the future as a Hungarian & 67.2 & 38.0 & 73.1 & 58.9 & 59.0 \\
Improving living conditions for self and & 28.6 & 47.0 & 76.1 & 49.5 & 53.6 \\
the family & 31.9 & 27.7 & 83.8 & 39.6 & 48.5 \\
Anxiety over the future of children & 48.7 & 12.7 & 4.6 & 85.4 & 37.7 \\
Family unification & 42.9 & 34.9 & 53.8 & 8.9 & 34.3 \\
Desperate economic situation & 73.1 & 23.5 & 20.8 & 28.1 & 32.9 \\
Rejection of minority status & 22.7 & 27.7 & 19.3 & 47.9 & 30.2 \\
Influence of friends and relatives & 47.1 & 41.6 & 25.4 & 13.5 & 29.4 \\
Attraction of Hungary/the image of & 12.6 & 84.3 & 7.1 & 2.1 & 25.9 \\
Better use of own skills and knowledge & 7.6 & 45.8 & 22.3 & 1.6 & 19.5 \\
Lack of professional opportunities & 2.5 & 15.1 & 8.1 & 18.8 & 11.9 \\
Marriage & 5.0 & 19.3 & 18.8 & 0.5 & 11.3 \\
Lack of Hungarian educational & 10.1 & 7.8 & 17.8 & 5.2 & 10.5 \\
Social conditions at home & 0.0 & 27.7 & 7.1 & 3.1 & 9.8 \\
Studies & 25.2 & 4.8 & 8.6 & 2.1 & 8.7 \\
Desperate political situation & 23.5 & 2.4 & 6.6 & 1.6 & 7.0 \\
Specific human rights grievance & 14.3 & 0.6 & 5.1 & 2.1 & 4.7 \\
\hline Fear (e.g. of ethnic conflicts) & 17.7 & 24.6 & 29.2 & 28.5 & 100.0
\end{tabular}

Source: Survey data

Another significant group is that of the family unificators comprising $28.5 \%$ of the respondents. Their primary motivation was family reunification $(85.4 \%$ mentioned this reason) but some of the migrants were placed here on account of marriages. Interestingly enough, in the case of this group the influence of friends and relatives seemed to have the greatest motivating power, which seems to suggest that family reunification - which, as we mentioned earlier, amounts mostly to older parents migrating to join their children - takes place in most cases because of the influence of the network's model.

The third type is that of career migrants, comprising a quarter of the respondents. These people were motivated in their migration decision by professional reasons: $84.3 \%$ cited "a better use of skills and knowledge" and an above-the-average portion of them (45.8\%) cited the lack of "professional advancement at home" as a motivation. Nearly $30 \%$ of them were educated in Hungary and this has also been mentioned as a motivation, just like the lack of Hungarian-language education institutions in Romania. In this group, besides professional reasons, the "attraction of Hungary" was frequently cited (41.2\%), conceivably because of better professional opportunities there. 
Finally, the fourth group is that of ethnic migrants, comprising $17.7 \%$ of the immigrants. For these people, rejection of their minority status was the primary motivation: nearly three quarters of them chose to emigrate as they "did not want to live in a minority." At the same time, these people cited the hopelessness of the political situation in Romania, human rights violations and ethnic problems at a rate far exceeding the average. It is in this group that the highest proportion of people (67.2\%) thought that migration secured their future as Hungarians and the attraction of the mother country is highest (47\%). It is noteworthy that only in this group does the economic push factor (i.e. hopelessness of the economic situation in the source country) outweigh the pull factor (i.e. the intent to improve living conditions).

Looking at the various socio-demographic features of the four types of immigrants, we can see that economic migrants come primarily from the younger age groups: $60 \%$ of them are under 35 and $32 \%$ are between 35-54. This type of migration occurs at an above-average frequency among males and those with a secondary school education. The majority of them arrived to Hungary two to four years prior to settling there, $26.4 \%$ of them for employment purposes, two thirds of them with a view to staying for good.

Most of the family unificators come from the older age groups: $58 \%$ of them are over 55 and $53 \%$ of them were pensioners before moving to Hungary. At the same time, nearly one third of them are under 35 - these people were motivated to migrate primarily by an intent to enter into marriage. This type is more frequent among women and the lower educated (on account of their older age). Most of them arrived in Hungary one or two years prior to settling.

The career migrants are the youngest group and the best educated: $84 \%$ of them are under 35 and $43 \%$ of them are university educated while a further $36 \%$ of them have a secondary school diploma. Nearly one third of them had been students prior to moving to Hungary and one fifth of them came to Hungary with an intent to continue their studies, not to stay. Many of them secured immigrant status after years of stay in Hungary: 38\% had stayed there for three to four years and $35 \%$ for an even longer period.

The composition of the ethnic migrants is very similar to that of the family unificators. This type is most frequently found among the elderly (pensioners) and the lower educated. There are, however, many young people among them as well: one third of them are under 35 . Most of them came to Hungary with the intent to stay for one or two years prior to settling.

As one can see, it is possible to create groups on the basis of the frequency of migratory motivations or the simultaneous occurrence of certain motivations - nevertheless 
these are not pure types. Both the family unificators and the career migrants cited such motivations as economic considerations and anxiety over the future, albeit with a lower frequency than the economic migrants did. A significant part of the ethnic migrants were also motivated by family reunification purposes as well.

\section{Conclusions}

In many of the segments of migration to Hungary - immigrants, official guest workers - those from Romania (and specifically Transylvania) are in the majority. In these groups, people of Hungarian ethnicity are overwhelmingly dominant. The peculiarity of the immigration of ethnic Hungarians from Romania to Hungary lies in the fact that ethnicity plays a stimulating and regulating role and the fact that, as a consequence of shared language and cultural traditions, the immigrants themselves do not regard their "move" as true migration.

For ethnic Hungarians from Transylvania, the primary motivations of the turnof-the-millennium migration to Hungary were the uncertain future in Romania, economic considerations and family reunification. In these, we find causes brought about by the society of origin (economic and social ones) intertwined with causes on the personal level (ones rooted in specific life situations, family ties, endeavors, wishes and plans). Ethnicity appears in this process as important network and cultural capital, but it plays an actual primary motivating role only within one narrow group.

The changes in the causes and motivations of migration and the shifting composition of the immigrants indicate that a "secondary migration" has commenced, which primarily sees elderly, pensioner-age parents migrating to join their children who moved across the border earlier. At the same time, the largely economically motivated "primary migration" remains very significant among younger people, just like professionally-motivated migration among those with a higher education. People in these categories were not following in the footsteps of family members but considered such factors as their circumstances at home, economic and professional perspectives, the future for themselves and their children when making their decision to migrate. In many cases, the decision to settle in Hungary was made after years of stay in that country.

The role of the networks plays a determining part in the migratory processes under analysis. The cultural patterns of the source society relevant to migration and the ever-multiplying number of ties - mostly a consequence of the unceasing migration between the Hungarian community in Transylvania and Hungary - make it very likely that migration will continue in the near future. Its intensity may be somewhat mitigated by the improvement of the economic situation in Romania or by Hungarian 
migration regulations, but in all probability, the outflow through family connections and the efforts at family reunification will probably not cease. All this, of course, has an impact of the source community: natural reproduction, which has been negative for some time, will be set back further by the emigration of young people, and the decrease in available labor force might slow down the growth of the economy.

Since 1980, the Hungarian population has been shrinking and aging. Immigration somewhat blunts these processes (though immigration of older people might tax the social security system), but immigration does not produce unequivocally desirable results for Hungary. An overwhelming majority of immigrants from neighboring countries are of Hungarian ethnicity. This also means that the Hungarian population in the countries of origin will shrink, their proportion vs. the majority population will drop further and because of the migration of young people, the aging of these populations will speed up. In the long run, this might mean that Hungary, which had lost significant portions of its territories in the political and economic sense, will lose them again in the cultural sense.

\section{References}

Ágoston, Erzsébet. 1994. Külföldiek magyarországi munkavállalása. [Employment of foreigners in Hungary] Munkaügyi Szemle 38(4):20-24.

Bodó, Julianna (ed.).1996. Elvándorlók? Vendégmunka és életforma a Székelyföldön. [Emigrants? Guest work and lifestyle in the Székely lands] KAM - Regionális és Antropológiai Kutatások Központja, Pro-Print Könyvkiadó, Csíkszereda, 1996, pp. 258.

Boyd, Monica. 1989. Family and personal networks in international migration: recent developments and new agendas. International Migration Review 23:638-70.

Brubaker, Rogers. 1998. Migrations of ethnic unmixing in the "New Europe". International Migration Review 32:1047-65.

Fawcett, James T. 1989. Networks, linkages and migration systems. International Migration Review, 1989 vol. 23.

Gödri, Irén. 1998. A romániai magyar értelmiségiek kivándorlásának motivációs háttere és ideológiai vonatkozásai. [The ideologogical aspects and motivational background of the emigration of the Hungarian intellectuals from Romania] Regio 9(3):75-101.

—. 2002. Beilleszkedés vagy elszigetelödés? [Integration or Isolation?] Korfa, 2002(1):4-5.

-. 2003a. Motivations and Features of Hungarian Immigration at the Turn of the Millennium. PopLar 2003, 10-11.

—. 2003b. A magyarországi bevándorlás okai és következményei. Kézirat. [The Causes and Consequences of Immigration to Hungary - Manuscript]. KSH NKI

Hablicsek, László and Pál Péter Tóth. 1996. A nemzetközi vándorlás hatása a magyarországi népesség számának alakulására 1944-2010 között. [Effect of international migration on the development of the number of the Hungarian population between 1994-2010] In: Táborlakók, diaszpórák, politikák [Refugees, Diasporas, Politics] edited by Endre Sik and Judit Tóth. Budapest. 
Hungarian Yearbook of Demography 1993, 1996, 2001 and 2002. Budapest.

Massey, S. Douglas, Joaquin Arango, Graeme Hugo, Ali Kouaouci, Adela Pelegrino, and J. Edward Taylor. 1993. Theories of International Migration: A Review and Appraisal. Population and Development Review 19(3):431-66.

—. 2001. Contemporary Theories of International Migration. In: Worlds in Motion. Understanding International Migration at the end of the Millennium, edited by Massey, D. S. et al. Oxford: Clarendon Press.

Münz, Rainer. 1998, Migráció Európában - kihívás Ausztria számára. [Migration in Europe - a challenge facing Austria]. Európai Szemle 9(3):93-101.

Örkény, Antal (ed.). 2003. Menni vagy maradni? Kedvezménytörvény és migrációs várakozások [To stay or to leave - Status Law and migrant expectations]. Budapest.

Romanian Statistical Yearbook 1993, 2002. Bucuresti.

Salt, John. 2001. Az európai migrációs térség. Regio 2001(3-4):177-203.

Sik, Endre. 1990. Erdélyi menekültek Magyarországon. [Transylvanian refugees in Hungary] In: Társadalmi riport 1990, edited by Andorka, Rudolf, Kolosi Tamás and Vukovich György. Budapest: TÁRKI.

Simonovits, Bori. 2003. A migrációs burok hatása a migrációs potenciálra a Kárpát-medencei magyarok körében. [The effect of the migratory bubble on migratory potential among Hungarians living in the Carpathian Basin]. In: Menni vagy maradni? Kedvezménytörvény és migrációs várakozások, edited by Örkény Antal. Budapest.

Tóth, Pál Péter. 1996a. International Migration and Hungary. Atlantic Studies on Society in Change, No. 85.

—. 1996b. Hungarians in the Successor States: from World War I to World War II. Nationalities Papers 24(3):425-35.

—. 1997. Haza csak egy van? Menekülök, bevándorlók, új állampolgárok Magyarországon 1988-1994. [Is There Only One Homeland? Refugees, Immigrants, New Citizens in Hungary 1988-1994]. Budapest: Püski Kiadó.

Varga, E. Árpád. 1998. Fejezetek a jelenkori Erdély népesedéstörténetéböl. [Chapters from the population history of present-day Transylvania]. Budapest: Püski Kiadó. 